\title{
Anti-Obesity Effects of Microalgae
}

\author{
Saioa Gómez-Zorita ${ }^{1,2,+} \mathbb{C}^{\circ}$, Jenifer Trepiana ${ }^{1,+}+\mathbb{C}$, Maitane González-Arceo ${ }^{1}$, Leixuri Aguirre ${ }^{1,2}$, \\ Iñaki Milton-Laskibar ${ }^{1,2} \mathbb{1}$, Marcela González ${ }^{3}$, Itziar Eseberri ${ }^{1,2, * \mathbb{C}}$, \\ Alfredo Fernández-Quintela ${ }^{1,2, *(\mathbb{D})}$ and María P. Portillo ${ }^{1,2}$ (D) \\ 1 Nutrition and Obesity Group, Department of Nutrition and Food Science, University of the Basque \\ Country (UPV/EHU) and Lucio Lascaray Research Institute, 01006 Vitoria, Spain; \\ saioa.gomez@ehu.eus (S.G.-Z.); jenifer.trepiana@ehu.eus (J.T.); maitanega14@gmail.com (M.G.-A.); \\ leixuri.aguirre@ehu.eus (L.A.); inaki.milton@ehu.eus (I.M.-L.); mariapuy.portillo@ehu.eus (M.P.P.) \\ 2 CIBEROBN Physiopathology of Obesity and Nutrition, Institute of Health Carlos III, 01006 Vitoria, Spain \\ 3 Nutrition and Food Science Department, Faculty of Biochemistry and Biological Sciences, National \\ University of Litoral and National Scientific and Technical Research Council (CONICET), \\ Santa Fe 3000, Argentina; maidagon@fbcb.unl.edu.ar \\ * Correspondence: itziar.eseberri@ehu.eus (I.E.); alfredo.fernandez@ehu.eus (A.F.-Q.); Tel.: +34-945014363 \\ (I.E.); Tel.: +34-945013066 (A.F.-Q.) \\ + These authors contributed equally to this work.
}

Received: 14 October 2019; Accepted: 17 December 2019; Published: 19 December 2019

\begin{abstract}
In recent years, microalgae have attracted great interest for their potential applications in nutraceutical and pharmaceutical industry as an interesting source of bioactive medicinal products and food ingredients with anti-oxidant, anti-inflammatory, anti-cancer, and anti-microbial properties. One potential application for bioactive microalgae compounds is obesity treatment. This review gathers together in vitro and in vivo studies which address the anti-obesity effects of microalgae extracts. The scientific literature supplies evidence supporting an anti-obesity effect of several microalgae: Euglena gracilis, Phaeodactylum tricornutum, Spirulina maxima, Spirulina platensis, or Nitzschia laevis. Regarding the mechanisms of action, microalgae can inhibit pre-adipocyte differentiation and reduce de novo lipogenesis and triglyceride (TG) assembly, thus limiting TG accumulation. Increased lipolysis and fatty acid oxidation can also be observed. Finally, microalgae can induce increased energy expenditure via thermogenesis activation in brown adipose tissue, and browning in white adipose tissue. Along with the reduction in body fat accumulation, other hallmarks of individuals with obesity, such as enhanced plasma lipid levels, insulin resistance, diabetes, or systemic low-grade inflammation are also improved by microalgae treatment. Not only the anti-obesity effect of microalgae but also the improvement of several comorbidities, previously observed in preclinical studies, has been confirmed in clinical trials.
\end{abstract}

Keywords: microalgae; obesity; triglyceride; adipose tissue; adipocyte; mice

\section{Introduction}

Microalgae are prokaryotic or eukaryotic microscopic single-cell organisms, found in fresh water and marine systems. They produce approximately half of the atmospheric oxygen and use the greenhouse gas carbon dioxide to grow photo-autotrophically. Together with bacteria, microalgae provide energy for all the trophic levels above them. Although microalgae show a great biodiversity, the ones most studied are Chlorella, Spirulina, Haematococus, Dunaniella y Scenedesmus.

Microalgae produce a great variety of compounds, such as photosynthetic pigments (carotenoids and chlorophylls), sterols, polyunsaturated fatty acids, vitamins, minerals, fiber, polysaccaharides, enzymes, peptides, and toxins. It is important to emphasize that the chemical composition of 
microalgae depends on the species and the cultivation conditions, such as temperature, illumination, $\mathrm{pH}, \mathrm{CO}_{2}$ supply, salt, and nutrients [1,2]. They have attracted great interest in recent years due to their potential applications in nutraceutical and pharmaceutical industries, and are a major source of bioactive medicinal products and food ingredients with anti-oxidant, anti-inflammatory, anti-cancer, and anti-microbial properties [2,3].

One of the potential application fields for the microalgae bioactive compounds is obesity, which has become a serious health problem due to its high prevalence, and because it is a major risk factor for a wide range of chronic diseases, including diabetes, cardiovascular diseases, and cancer [4-6]. Nowadays, approved new-generation anti-obesity medications offer a safe and tolerable adjunct to lifestyle interventions for the majority of individuals with obesity. Nevertheless, depending on patient tolerability to side effects, poor adherence or discontinuation can be treatment limitations. In fact, this situation reduces treatment benefits [7].

In this context, the present review gathers in vitro and in vivo studies addressed to analyze the anti-obesity effects of microalgae extracts, but not those where isolated microalgae compounds have been used.

\section{In Vitro Studies}

To date, several in vitro studies have been conducted to analyze the effects of microalgae extracts on adipogenesis and metabolic processes involved in triglyceride (TG) accumulation (Table 1; Figure 1).
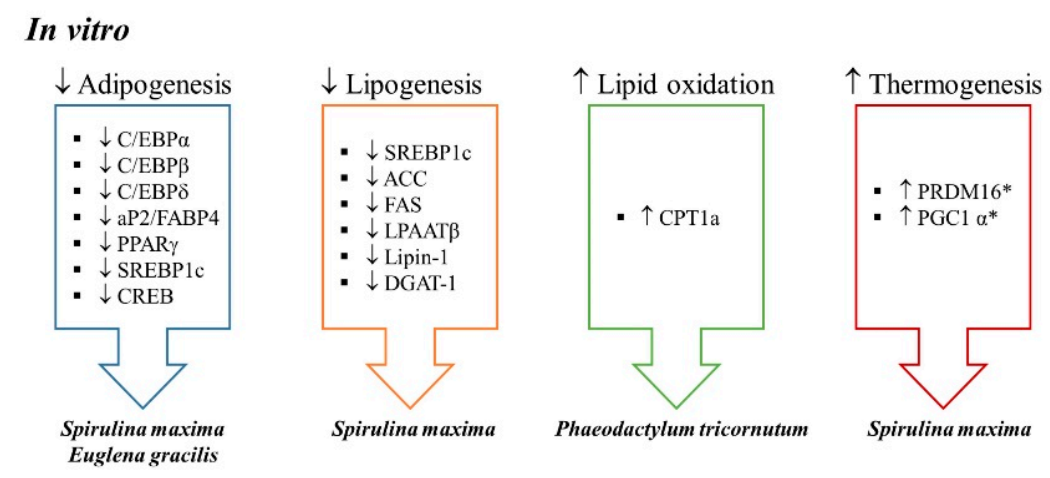

Figure 1. Anti-obesity mechanisms of action described in in vitro studies (* ex vivo). ACC: acetyl-CoA carboxylase, AP2: fatty acid binding protein, C/EBP: CCAAT-enhancer-binding protein, CPT1: carnitine palmitoyltransferase 1, CREB: cAMP regulatory element-binding protein; DGAT-1: diacylglycerol O-acyltransferase, FABP4: fatty acid-binding protein 4, FAS: fatty acid synthase, LPAAT $\beta$ : lysophosphatidic acid acyltransferase $\beta$, PGC- $1 \alpha$ : peroxisome proliferator-activated receptor gamma co-activator $1 \alpha$, PRDM16: PR domain-containing 16, PPAR $\gamma$ : peroxisome proliferator activated receptor $\gamma$, SREBP1c: sterol regulatory element-binding protein $1 \mathrm{c}$. $\uparrow$ significant increase, $\downarrow$ : significant decrease.

Sugimoto et al. [8] used an aqueous extract of Euglena gracilis Z (Euglena), unicellular photosynthesizing green algae. Euglena contains vitamins, minerals, unsaturated fatty acids, and accumulates crystalline $\beta$-1,3-glucan, a polysaccharide also known as paramylon, which is considered a functional dietary fiber. The authors obtained human adipose-derived stem cells (hASCs) from a non-diabetic female donor with a body mass index (BMI) of $26 \mathrm{~kg} / \mathrm{m}^{2}$, and differentiated these cells into adipocytes for 7 days ( $0-7$ days). Cells were cultured for an additional 7-day maturing period (8-14 days). Cytotoxicity was not observed in cells treated with any of the checked Euglena extract dilutions used $(1.25 \%, 2.5 \%, 5 \%, 10 \%, 20 \%$, or $40 \%)$. When the lipid content of cells incubated with the extract at doses of $5 \%, 10 \%$, or $20 \%$ was analyzed, the authors observed that Euglena extract reduced cellular TG content $17 \%, 44 \%$, and $74 \%$, in line with the increased concentration of the extract in the medium. 
Table 1. Effects of microalgae in pre-adipocytes and mature adipocytes.

\begin{tabular}{|c|c|c|c|c|c|}
\hline Reference Numbers & Cell Line & Microalgae and Doses & Experimental Design & Effects & Mechanisms \\
\hline [8] & $\begin{array}{l}\text { Human adipose-derived } \\
\text { stem cells }\end{array}$ & $\begin{array}{l}\text { Euglena gracilis Z extract } \\
(5 \%, 10 \% \text {, or } 20 \%)\end{array}$ & $\begin{array}{l}\text { Cells were treated during } \\
\text { differentiation } \\
\text { ( } 7 \text { days) and adipocyte } \\
\text { maturation } \\
\text { ( } 7 \text { additional days) }\end{array}$ & $\begin{array}{l}\text { At } 10 \% \text { and } 20 \% \text { : } \\
\downarrow \text { lipid content } 44 \% \text { and } \\
74 \% \text { respectively } \\
\text { At } 20 \% \text { : } \\
\downarrow \text { Adipogenesis }\end{array}$ & $\begin{array}{l}\text { At } 20 \% \text { : } \\
\downarrow \mathrm{C} / \mathrm{EBP} \alpha \text { and PPAR } \gamma \text { gene and } \\
\text { protein expressions } \\
\downarrow C r e b, \text { Srebp } 1 c, C / e b p \beta \text { and } C / e b p \delta \\
\text { gene expression } \\
\downarrow \text { Fabp4 and } L p l \text { gene expression }\end{array}$ \\
\hline \multirow[t]{2}{*}{ [9] } & 3T3-L1 pre-adipocytes & $\begin{array}{l}\text { Spirulina maxima extract (50 } \\
\text { and } 100 \mu \mathrm{g} / \mathrm{mL} \text { ) }\end{array}$ & $\begin{array}{l}\text { Cells were treated on day } 0,2,4 \text {, } \\
\text { and } 6 \text { of differentiation (cell } \\
\text { harvesting on day } 8 \text { ) }\end{array}$ & $\begin{array}{l}\text { At } 100 \mu \mathrm{g} / \mathrm{mL}: \\
\downarrow \text { Adipogenesis (dose } \\
\text { dependent) }\end{array}$ & $\begin{array}{l}\text { At } 100 \mu \mathrm{g} / \mathrm{mL}: \\
\downarrow \text { FAS and C/EBP } \alpha \text { protein } \\
\text { expression } \\
\text { At } 50 \text { and } 100 \mu \mathrm{g} / \mathrm{mL} \text { : } \\
\downarrow \text { PPAR } \gamma \text { and } \mathrm{aP} 2 \text { protein } \\
\text { expression } \\
\downarrow \text { SREBP1c, ACC, LPAAT } \beta, \text { lipin } 1 \text {, } \\
\text { and DGAT-1 protein expression }\end{array}$ \\
\hline & $\begin{array}{l}\mathrm{C} 3 \mathrm{H} 10 \mathrm{~T} 1 / 2 \text { mesenchymal } \\
\text { stem cells }\end{array}$ & $\begin{array}{l}\text { Spirulina maxima extract } \\
(100 \mu \mathrm{g} / \mathrm{mL})\end{array}$ & $\begin{array}{l}\text { Cells were treated on day } 0,2,4 \text {, } \\
\text { and } 6 \text { of differentiation (cell } \\
\text { harvesting on day } 8 \text { ) }\end{array}$ & $\downarrow$ Adipogenesis & $\begin{array}{l}\downarrow \mathrm{C} / \mathrm{EBP} \alpha, \text { PPAR } \gamma \text {, and aP2 } \\
\text { protein expression } \\
\downarrow \text { SREBP1c, FAS, ACC, LPAAT } \beta, \\
\text { lipin1 and DGAT-1 protein } \\
\text { expression }\end{array}$ \\
\hline [10] & 3T3-L1 pre-adipocytes & $\begin{array}{l}\text { Phaeodactylum tricornutum } \\
\text { extract ( } 250 \text { and } 400 \mu \mathrm{g} / \mathrm{mL})\end{array}$ & $\begin{array}{l}\text { Cells were treated during } \\
\text { differentiation } \\
\text { ( } 6 \text { days) }\end{array}$ & $\begin{array}{l}\text { At } 250 \mu \mathrm{g} / \mathrm{mL} \\
\downarrow \text { Lipid accumulation } \\
\text { At } 400 \mu \mathrm{g} / \mathrm{mL} \\
\downarrow \text { Adipogenesis }\end{array}$ & $\begin{array}{l}\text { At } 400 \mu \mathrm{g} / \mathrm{mL} \\
\downarrow \text { PPAR } \gamma \text { and } \uparrow \mathrm{UCP} 1 \text { protein } \\
\text { expression }\end{array}$ \\
\hline [11] & 3T3-L1 pre-adipocytes & $\begin{array}{l}\text { Phaeodactylum tricornutum } \\
\text { extract } \\
(100 \mathrm{mg} / \mathrm{L})\end{array}$ & $\begin{array}{l}\text { Ceils were treated on day } 7 \text { of } \\
\text { differentiation for } 24 \mathrm{~h} \text { (cell } \\
\text { harvesting on day } 8 \text { ) }\end{array}$ & $\begin{array}{l}\text { No differences in lipid } \\
\text { content or cytotoxicity }\end{array}$ & $\uparrow C d 36$ and $C p t 1$ gene expression \\
\hline
\end{tabular}

Special note: Doted lines incorporated for separation between different studies. ACC: Acetyl-CoA carboxylase, AP2: fatty acid binding protein, C/EBP: CCAAT-enhancer-binding protein, CD36: cluster of differentiation 36, CPT1: carnitine palmitoyltransferase 1, CREB: cAMP regulatory element-binding protein; DGAT-1: diacylglycerol O-acyltransferase, FABP4: fatty acid-binding protein 4, FAS: fatty acid synthase, LPAAT $\beta$ : lysophosphatidic acid acyltransferase $\beta$, LPL: lipoprotein lipase, PPAR $\gamma$ : peroxisome proliferator activated receptor $\gamma$, SREBP1c: sterol regulatory element-binding protein 1c, UCP: uncoupling protein. $\uparrow$ significant increase, $\downarrow$ : significant decrease. 
In order to explore the mechanism underlying this effect, the authors studied the adipogenic pathway. Adipogenesis is a tightly regulated cellular differentiation process, which allows adipose tissue expansion. In this process, mesenchymal stem cells become pre-adipocytes and pre-adipocytes differentiate into mature adipocytes, the cells that are able to accumulate triglycerides into lipid droplets [12]. For this purpose, they measured gene and protein expressions of peroxisome proliferator-activated receptor $\gamma(\mathrm{PPAR} \gamma)$ and CCAAT-enhancer-binding protein $\alpha(\mathrm{C} / \mathrm{EBP} \alpha)$, the master regulators of adipocyte-differentiation. While the gene expression of Ppar $\gamma$ and C/ebp $\alpha$ were increased during adipocyte-differentiation in the control cells, these were repressed by $23 \%$ when $20 \%$ of Euglena extract was added to the medium. Protein amounts of PPAR $\gamma$ and C/EBP $\alpha$ were also significantly reduced, which is consistent with this result. The authors also observed an inhibition induced by the Euglena extract in gene expression of adipogenic markers expressed downstream in the adipocyte differentiation process, and regulated by $\operatorname{PPAR} \gamma$ and $\mathrm{C} / \mathrm{EBP} \alpha$, such as fatty acid binding protein (Ap2) (also known as fatty acid bonding protein 4, Fabp4) and lipoprotein lipase ( $\mathrm{Lpl}$ ). These results show that Euglena extract inhibits adipocyte-differentiation through suppression of master regulators involved in that metabolic pathway.

Furthermore, since Ppary expression is enhanced at the early phase of adipocyte-differentiation by two members of the C/EBP protein family, C/EBP $\beta$ and C/EBP $\delta$, as well as by sterol regulatory element-binding transcription factor 1c (SREBP1c) and cAMP regulatory element-binding protein (CREB), their gene expression was also determined in hASCs. For this purpose, cells were cultured with or without Euglena extract $(20 \%)$ during the first three days in the differentiation process. All these genes were downregulated when Euglena extract was present in the medium, showing that its inhibitory effect on adipocyte-differentiation was caused by repressing the early stage of adipocyte-differentiation. These observations were confirmed when adipogenesis was evaluated by determining Oil Red O from cells treated with $20 \%$ of extract during adipocyte-differentiation (days $0-7$ ) and from those cells treated during adipocyte maturation (days 8-14). Constant supplementation (day $0-14$ ) with Euglena extract inhibited lipid accumulation by approximately $50 \%$ as compared to the control cells. When supplementation with the alga extract took place only during the adipocyte differentiation period (days 0-7) lipid accumulation was inhibited by $60 \%$, but approximately $96 \%$ of the accumulated lipids remained in the cells treated with the extract on days 7-14. Therefore, the authors concluded that Euglena extract suppresses adipocyte-differentiation at the early stage, thus contributing to its anti-obesity effect.

Another microalga studied by several authors is Spirulina maxima. It contains pigment proteins such as chlorophyll a and C-phycocyanin, which have been reported as possessing anti-oxidant, anti-inflammatory (both pigments), and anti-diabetic actions (C-phycocyanin). Seo et al. [9] performed an in vitro study to explore whether an ethanolic extract of this microalga also showed anti-obesity and adipocyte browning properties. For this purpose, 3T3-L1 pre-adipocytes and C3H10T1/2 cells, a cellular line functionally similar to mesenchymal stem cells, were treated during the differentiation period (0-8 days) with 50 or $100 \mu \mathrm{g} / \mathrm{mL}$ of the microalga extract. Previously no cytotoxicity had been confirmed at these concentrations. In 3T3-L1 pre-adipocytes, the addition of the extract to the differentiation medium decreased TG accumulation in a dose dependent manner. This effect was due to lower protein expression of the adipogenic regulators $\mathrm{C} / \mathrm{EBP} \alpha, \operatorname{PPAR} \gamma$, and aP2, meaning that adipogenesis was inhibited. The same results were observed when the authors treated C3H10T1/2 cells with the extract at a concentration of $100 \mu \mathrm{g} / \mathrm{mL}$.

In addition, the authors explored lipogenesis, the metabolic process through which fatty acids are esterified with glycerol for their storage as triglycerides, and that allows adipocytes to increase their size. More specifically, the authors measured enzymes involved in de novo lipogenesis, the biosynthetic pathway by which acetyl-CoA is converted to fatty acids before they are esterified with glycerol to synthesize triglycerides. For that purpose, authors measured proteins such as acyl-CoA carboxylase (ACC) and fatty acid synthase (FAS), as well as markers involved in triglyceride assembly, such as lysophosphatidic acid acyltransferase $\beta$ (LPAAT $\beta$ ), lipin-1 and diacylglycerol acyltransferase-1 
(DGAT1). In this regard, they observed that treating 3T3-L1 pre-adipocytes during differentiation with the ethanolic extract led to reductions in the protein expressions of SREBP1, ACC, and FAS, as well as of LPAAT $\beta$, lipin-1, and DGAT1. As far as C3H10T1/2 cells are concerned, incubating cells with the extract obtained from Spirulina maxima during differentiation reduced protein expressions of the three latter lipogenic markers (LPAAT $\beta$, lipin-1, and DGAT1). The authors concluded that this extract significantly suppressed lipogenesis either in 3T3-L1 adipocytes or C3H10T1/2 cells. Finally, the authors reported browning effects ex vivo, in cells obtained from the stromal vascular fraction of mice fed a high-fat diet (HFD) supplemented with an ethanolic extract of the alga (150 or $450 \mathrm{mg} / \mathrm{kg} / \mathrm{day}$ ). Cells were differentiated into white adipocytes, and higher protein expression of PR domain containing 16 (PRDM16) and uncoupling protein 1 (UCP1) was detected in the adipose primary cells. The expression of peroxisome proliferator-activated receptor gamma coactivator 1-alpha (PGC1 $\alpha$ ) was upregulated only by the higher dose.

Using Phaeodactylum tricornutum, a diatom microalga rich in eicosapentanoic acid (EPA) and the carotenoid fucoxanthin, Koo et al. [10] aimed to evaluate the anti-obesity effect of a commercially available extract, containing 3.5-6\% fucoxanthin $(w / w)$, on lipid accumulation in 3T3-L1 adipocytes. The cells were cultured during the differentiation period for six days with the Phaeodactylum tricornutum extract $(100,125,200,250$, and $400 \mu \mathrm{g} / \mathrm{mL}$ ), fucoxanthin (active principle; 10, 20, and $40 \mu \mathrm{g} / \mathrm{mL}$ ) or curcumin as control $(20 \mu \mathrm{g} / \mathrm{mL})$. The microalga extract reduced adipogenesis in 3T3-L1 preadipocytes at a concentration of $250 \mu \mathrm{g} / \mathrm{mL}$, and consequently reduced cellular lipid accumulation was observed. When looking at the mechanisms underlying this effect, the authors reported that although no changes were observed in the protein expression of the adipogenic factor C/EBP $\alpha$, Phaeodactylum tricornutum extract decreased PPAR $\gamma$ protein expression and increased that of UCP1, mainly at the highest dose $(400 \mu \mathrm{g} / \mathrm{mL})$. Therefore, the authors concluded that Phaeodactylum tricornutum extract exhibits anti-obesity effects by controlling lipid metabolism through PPAR $\gamma$ and UCP1.

Finally, Gille et al. [11] incubated 3T3-L1 cells on day 7 of differentiation with an ethanolic extract of the same microalga, at a dose of $100 \mathrm{mg} / \mathrm{L}$ for $24 \mathrm{~h}$. Moreover, they also tested its bioactive compound fucoxanthin at a concentration of $5 \mu \mathrm{M}$. According to the authors, each $100 \mathrm{mg} / \mathrm{L}$ of the microalga contained $3.6 \mu \mathrm{M}$ of fucoxanthin. Regarding the microalga effect, the authors did not appreciate significant effects on lipid content or cell toxicity, although cluster of differentiation $36(C d 36)$ and carnitine palmitoyltransferase 1a (Cpt1a) mRNA levels were significantly increased. Furthermore, Cpt1a gene expression was similarly induced by fucoxanthin incubation. Consequently, it can be proposed that the effect of the microalga extract on Cpt1a expression were due, at least in part, to its fucoxanthin content.

\section{Animal Studies}

Studies using animal models and different experimental approaches to analyze the potential anti-obesity effect of microalgae have revealed beneficial effects on body weight management and energy metabolism (Table 2; Figure 2). 
Table 2. Effects of microalgae in animal studies.

\begin{tabular}{|c|c|c|c|c|c|}
\hline Reference Numbers & Animal Model & Microalgae and Doses & Experimental Design & Effects & Mechanisms \\
\hline [9] & $\begin{array}{l}\text { Male ICR mice } \\
\text { (4 weeks old) }\end{array}$ & $\begin{array}{l}\text { Spirulina maxima extract } \\
\text { (SM70EE; } 150 \text { and } \\
450 \mathrm{mg} / \mathrm{kg} \mathrm{BW} / \text { day) } \\
6 \text { weeks }\end{array}$ & $\begin{array}{l}\text { HFD: high-fat diet }(60 \% \text { of } \\
\text { energy from fat) } \\
\text { SM150: HFD + SM70EE } \\
150 \mathrm{mg} / \mathrm{kg} \text { BW/day } \\
\text { SM450: HFD + SM70EE } \\
450 \mathrm{mg} / \mathrm{kg} \mathrm{BW/day}\end{array}$ & $\begin{array}{l}\text { SM450 group: } \\
\uparrow \text { Serum HDL-c } \\
\text { SM150 and SM450 groups: } \\
\downarrow \text { Final body weight } \\
\downarrow \text { Body weight gain } \\
\downarrow \text { Subcutaneous and abdominal } \\
\text { WAT } \\
\downarrow \text { Serum TG, TC, LDL-c and } \\
\text { glucose levels } \\
\downarrow \text { Adipogenesis in WAT }\end{array}$ & $\begin{array}{l}\text { SM450 group: } \\
\uparrow \text { pAMPK, PRDM16 and PGC1 } \alpha \text { protein } \\
\text { expression in WAT } \\
\uparrow \text { UCP1 protein expression in BAT } \\
\text { SM150 and SM450 groups: } \\
\downarrow \text { C/EBP } \alpha, \text { PPAR } \gamma, \text { and aP2 protein } \\
\text { expression in WAT } \\
\uparrow \text { UCP1 protein expression in WAT } \\
\uparrow \text { PRDM16 protein expression in BAT }\end{array}$ \\
\hline [13] & $\begin{array}{l}\text { Male Sprague-Dawley } \\
\text { rats } \\
\text { ( } 5 \text { weeks old) }\end{array}$ & $\begin{array}{l}\text { Spirulina maxima } \\
(62.5,125, \text { and } 250 \mathrm{mg} / \mathrm{kg} \\
\text { BW/day) } \\
4 \text { weeks }\end{array}$ & $\begin{array}{l}\text { LFD: low-fat diet }(10 \% \text { of } \\
\text { energy from fat) } \\
\text { HFD: high-fat diet }(60 \% \text { of } \\
\text { energy from fat) } \\
\text { SM 62.5: HFD }+62.5 \mathrm{mg} / \mathrm{kg} \\
\text { BW/day } \\
\text { SM 125: HFD }+125 \mathrm{mg} / \mathrm{kg} \\
\text { BW/day } \\
\text { SM 250: HFD }+250 \mathrm{mg} / \mathrm{kg} \\
\text { BW/day of }\end{array}$ & $\begin{array}{l}\text { SM 62.5, 125, and } 250 \text { SM groups: } \\
\downarrow \text { Epididymal adipocyte size } \\
\uparrow \text { Brown adipose tissue index } \\
\uparrow \text { Serum adiponectin } \\
\downarrow \text { Serum TNF- } \alpha \\
\downarrow \text { HOMA-IR } \\
\uparrow \text { Serum HDL-c/TC } \\
\downarrow \text { Serum ALT } \\
\text { SM } 125 \text { and SM } 250 \text { groups: } \\
\downarrow \text { Body weight gain } \\
\uparrow \text { Brown adipose tissue } \\
\downarrow \text { Serum leptin } \\
\downarrow \text { Serum insulin } \\
\downarrow \text { Serum TC } \\
\text { SM } 250 \text { group: } \\
\downarrow \text { Epididymal adipose tissue index } \\
\downarrow \text { Serum glucose }\end{array}$ & $\begin{array}{l}\text { SM } 125 \text { and SM } 250 \text { groups: } \\
\downarrow \text { FAS protein expression (epididymal AT) } \\
\downarrow \text { Fasn gene expression (epididymal AT) } \\
\uparrow \text { AdipoR gene expression (epididymal AT) } \\
\uparrow \text { pAMPK protein expression (epididymal } \\
\text { AT and skeletal muscle) } \\
\uparrow \text { AdipoR1, Cpt1 and } \text { Ucp } 2 \text { gene expression } \\
\text { (skeletal muscle) } \\
\downarrow \text { Srebf1 and Nfk } \beta \text { gene expression } \\
\text { (epididymal AT) } \\
\text { SM } 250 \text { group: } \\
\uparrow \text { Atgl and Cpt1 gene expression (epididymal } \\
\text { AT) } \\
\text { The dose is not specified: } \\
\uparrow \text { pACC, AdipoR1, NAMPT, and SIRT1 } \\
\text { protein expression (epididymal AT) } \\
\downarrow \text { SREBP1 and FAS protein expression } \\
\text { (epididymal AT) } \\
\uparrow \text { AdipoR1, NAMPT and SIRT1 protein } \\
\text { expression (skeletal muscle) }\end{array}$ \\
\hline [11] & $\begin{array}{l}\text { Male C75BL/6J mice } \\
\text { (6-8 weeks old) }\end{array}$ & $\begin{array}{l}\text { Phaeodactylum tricornutum } \\
\text { (PE) extract } \\
(100 \text { and } 300 \mathrm{mg} / \mathrm{kg} \\
\text { BW/day) } \\
26 \text { days }\end{array}$ & $\begin{array}{l}\text { HFD: high-fat diet } 45 \% \text { of } \\
\text { energy from fat) } \\
\text { PE100: HFD + PE } 100 \mathrm{mg} / \mathrm{kg} \\
\text { BW/day } \\
\text { PE300: HFD + PE } 300 \mathrm{mg} / \mathrm{kg} \\
\text { BW/day }\end{array}$ & $\begin{array}{l}\text { PE300 group: } \\
\downarrow \text { Final body weight } \\
\downarrow \text { Total body fat mass } \\
\downarrow \text { Epididymal and inguinal tissue } \\
\downarrow \text { Adiposity index } \\
\uparrow \text { Energy expenditure } \\
\\
\text { PE100 and PE300 group: } \\
\uparrow \% \text { of small adipocytes in inguinal } \\
\text { WAT }\end{array}$ & $\begin{array}{l}\text { PE100 group: } \\
\uparrow C d 36 \text { and Ppargc1a gene expression in BAT } \\
\\
\text { PE300 group: } \\
\downarrow \text { Lipe, Plin1, and Lpl gene expression in } \\
\text { epididymal WAT } \\
\uparrow \text { Ucp } 1 \text { and Cpt gene expression in inguinal } \\
\text { WAT } \\
\uparrow \text { BAT activation } \\
\text { PE100 and PE300 group: } \\
\downarrow \text { Lipe and Fasn gene expression in BAT } \\
\uparrow \text { UCP1 protein expression in BAT }\end{array}$ \\
\hline
\end{tabular}


Table 2. Cont.

\begin{tabular}{|c|c|c|c|c|c|}
\hline Reference Numbers & Animal Model & Microalgae and Doses & Experimental Design & Effects & Mechanisms \\
\hline [10] & $\begin{array}{l}\text { Female C57BL/6J mice } \\
\text { (8 weeks old) }\end{array}$ & $\begin{array}{l}\text { Phaeodactylum tricornutum } \\
\text { (PE) extract } \\
(0.81,1.62 \text {, and } 3.25 \mathrm{mg} / \mathrm{kg} \\
\text { BW/day) } \\
6 \text { weeks }\end{array}$ & $\begin{array}{l}\text { HFD: High-fat diet } \\
\text { PE-L: HFD + PE } \\
0.81 \mathrm{mg} / \mathrm{kg} \text { BW/day } \\
\text { PE-M: HFD + PE } 1.62 \mathrm{mg} / \mathrm{kg} \\
\text { BW/day } \\
\text { PE-H: HFD + PE } 3.25 \mathrm{mg} / \mathrm{kg} \\
\text { BW/day }\end{array}$ & $\begin{array}{l}\text { PE-H group: } \\
\downarrow \text { Plasma LDL-c } \\
\text { PE-M group: } \\
\downarrow \text { Plasma TG } \\
\text { PE-M and PE-H groups: } \\
\downarrow \text { Subcutaneous fat volume } \\
\text { PE-L, PE-M and PE-H groups: } \\
\downarrow \text { Body weight gain } \\
\downarrow \text { inguinal fat depots } \\
\downarrow \text { Total and abdominal fat volume }\end{array}$ & $\begin{array}{l}\text { PE-H group: } \\
\downarrow \text { C/EBP } \alpha \text { protein expression in WAT } \\
\\
\text { PE-M and PE-H groups: } \\
\uparrow \text { UCP1 protein expression in WAT } \\
\\
\text { PE-L, PE-M, and PE-H groups: } \\
\text { PPAR } \gamma \text { protein expression in WAT }\end{array}$ \\
\hline [14] & $\begin{array}{l}\text { Male C57BL/6J mice } \\
\text { (10 weeks old) }\end{array}$ & $\begin{array}{l}\text { Euglena gracilis extract } \\
(1 \%) \\
8 \text { weeks }\end{array}$ & $\begin{array}{l}\text { Standard diet } \\
\text { Standard diet + Euglena gracilis } \\
\text { extract }\end{array}$ & $\begin{array}{l}\downarrow \text { Total, perinephric, and } \\
\text { epididymal adipose tissue }\end{array}$ & $\uparrow$ Lipe gene expression in epididymal WAT \\
\hline [15] & $\begin{array}{l}\text { Male C57BL/6J mice } \\
\text { (10 weeks old) }\end{array}$ & $\begin{array}{l}\text { Nitzschia laevis extract } \\
\text { (10 or } 50 \mathrm{mg} / \mathrm{kg} \text { BW/day) } \\
8 \text { weeks }\end{array}$ & $\begin{array}{l}\text { HFD ( } 24 \% \text { of energy from fat) } \\
\text { HFD+ } 10 \mathrm{mg} / \mathrm{kg} \text { BW/day of } \\
\text { Nitzschia laevis extract } \\
\text { HFD+ } 50 \mathrm{mg} / \mathrm{kg} \text { BW/day of } \\
\text { Nitzschia laevis extract }\end{array}$ & $\begin{array}{l}50 \mathrm{mg} / \mathrm{kg} \mathrm{BW} / \text { day: } \\
\downarrow \text { Body weight } \\
\downarrow \text { Liver weight and lipid } \\
\text { accumulation } \\
\text { Improved gut epithelium integrity } \\
10 \text { and } 50 \mathrm{mg} / \mathrm{kg} \text { BW/day: } \\
\downarrow \text { Epididymal adipose tissue weight } \\
\text { and adipocyte diameter } \\
\uparrow \text { BAT adipocyte number } \\
\text { Improved gut microbiota richness } \\
\text { and diversity } \\
\uparrow \text { Firmicutes/Bacteroidetes ratio }\end{array}$ & $\begin{array}{l}10 \mathrm{mg} / \mathrm{kg} \text { BW/day: } \\
\uparrow P g c-1 \alpha \text { gene expression in BAT } \\
50 \mathrm{mg} / \mathrm{kg} \text { BW/day: } \\
\uparrow \text { Occludin gene expression } \\
10 \text { and } 50 \mathrm{mg} / \mathrm{kg} \text { BW/day: } \\
\uparrow \text { Ucp } 1 \text { gene expression in BAT }\end{array}$ \\
\hline
\end{tabular}

Special note: Doted lines incorporated for separation between different studies. ACC: Acetyl-CoA carboxylase, AdipoR1: adiponectin receptor 1, ALT: alanine aminotransferase, AMPK: AMP-activated protein kinase, AP2: fatty acid binding protein, AT: adipose tissue, ATGL: adipose triglyceride lipase, BAT: brown adipose tissue, BW: body weight, CD36: cluster of differentiation 36, C/EBP $\alpha$ : CCAAT-enhancer-binding protein $\alpha$, CPT: carnitine palmitoyltransferase, FAS: fatty acid synthase, Fasn: fatty acid synthase (gene), HDL-c: high-density lipoprotein cholesterol, HFD: high-fat diet, HOMA-IR: Homeostatic Model Assessment of Insulin Resistance, ICR: Institute of Cancer Research, IR: insulin resistance, LDL-c: low-density lipoprotein cholesterol, LIPE: hormone sensitive lipase, LPL: lipoprotein lipase, NAMPT: nicotinamide phosphoribosyltransferase, NFkB: nuclear factor kB, PGC-1 $\alpha$ : peroxisome proliferator-activated receptor gamma co-activator 1 $\alpha$, PLIN1: perilipin 1, PPAR $\gamma$ : peroxisome proliferator activated receptor $\gamma$, PPARGC1a: PPARG coactivator 1 alpha, PRDM16: PR domain-containing16, SIRT1: sirtuin 1, SREBP1: sterol regulatory element-binding protein 1, TC: total cholesterol, TG: triglycerides, TNF- $\alpha$ : tumor necrosis factor $\alpha$, UCP1: uncoupling protein 1, WAT: white adipose tissue. $\uparrow$ significant increase, $\downarrow$ : significant decrease. 


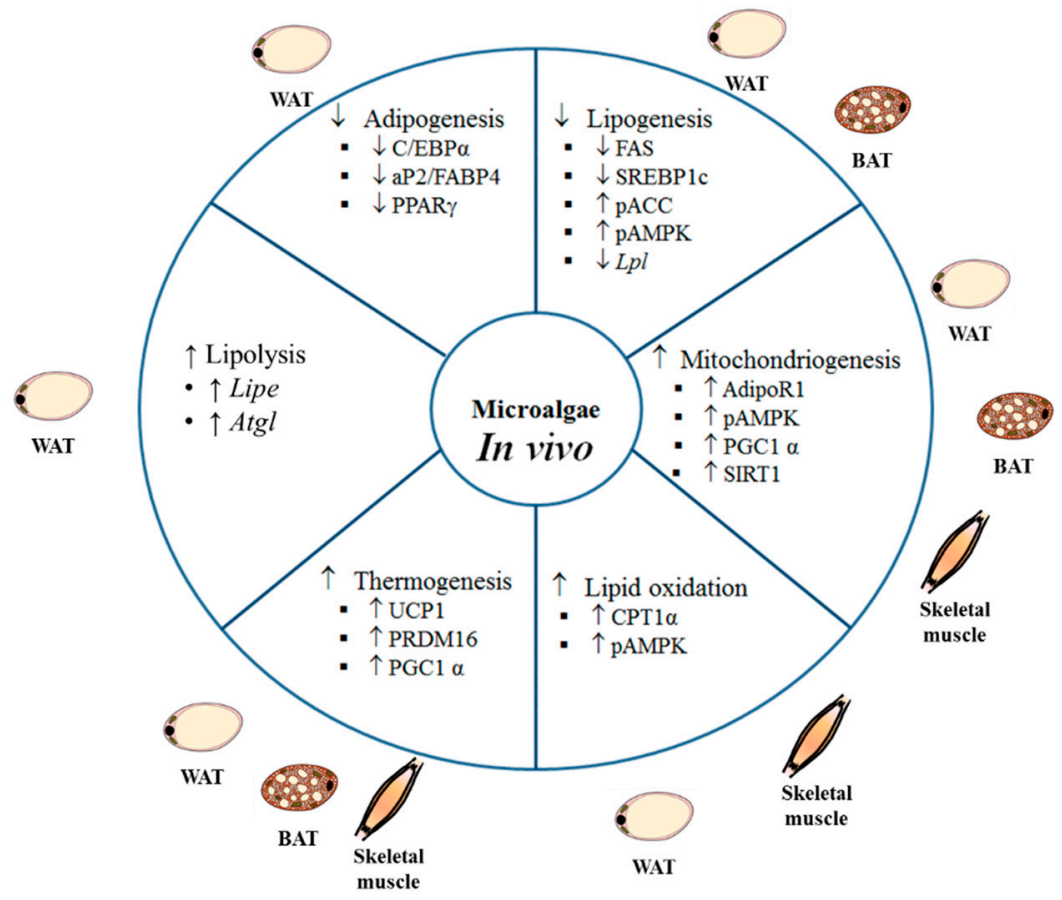

Figure 2. Anti-obesity mechanisms of action described in in vivo studies. pACC: phosphorylated acetyl-CoA carboxylase, AdipoR1: adiponectin receptor 1, pAMPK: phosphorylated AMP-activated protein kinase, AP2: fatty acid binding protein, BAT: brown adipose tissue, $\mathrm{C} / \mathrm{EBP} \alpha$ : CCAAT-enhancer-binding protein $\alpha, \mathrm{CPT}$ : carnitine palmitoyltransferase, FABP: fatty acid binding protein, FAS: fatty acid synthase, LIPE: hormone sensitive lipase, LPL: lipoprotein lipase, PGC-1 $\alpha$ : peroxisome proliferator-activated receptor gamma co-activator $1 \alpha, \operatorname{PPAR} \gamma$ : peroxisome proliferator activated receptor $\gamma$, PGC1 $\alpha$ : PPARG coactivator 1 alpha, PRDM16: PR domain-containing 16, SIRT1: sirtuin 1, SREBP1c: sterol regulatory element-binding protein 1c, UCP1: uncoupling protein 1, WAT: white adipose tissue. $\uparrow$ significant increase, $\downarrow$ : significant decrease.

Seo et al. [9] carried out a study in Male Institute of Cancer Research (ICR) mice fed either a standard $\operatorname{diet}$ (SD; $18 \%$ of energy from fat) or a high-fat diet (HFD; $60 \%$ of energy from fat), supplemented or not with a commercially available ethanolic extract of Spirulina maxima at doses of 150 or $450 \mathrm{mg} / \mathrm{kg}$ body weight/day, for 6 weeks. Supplementation of the HFD with the microalga extract led to a significant reduction both in body weight gain as well as in subcutaneous and visceral adipose tissues, but a dose-dependent response was not observed. In addition, after the treatment, decreases in fasting glucose, TG, total cholesterol (TC), and low-density lipoprotein cholesterol (LDL-cholesterol), as well as increases in high-density lipoprotein cholesterol (HDL-cholesterol), were observed.

By exploring the mechanisms responsible for the anti-obesity of the microalga extract, the authors observed lower protein expressions of adipogenesis and browning markers in white adipose tissue of mice fed the HFD supplemented with the extract. Thus, the authors detected a decrease in protein expression of $\mathrm{C} / \mathrm{EBP} \alpha, \mathrm{PPAR} \gamma$, and $\mathrm{aP} 2$, with both extract doses. They also found increased expression of proteins related to thermogenesis, such as PRDM16 and PGC1 $\alpha$, not only in brown but also in white adipose tissue. These results suggest that the extract obtained from Spirulina maxima ameliorated the obesity induced by HFD by decreasing adipogenesis and increasing energy expenditure via thermogenesis.

Heo et al. [13] also tested the effects of Spirulina maxima, but in this case in rats. In their study, Sprague Dawley rats were fed a standard-fat diet (LFD group; $10 \%$ of energy from fat) or a HFD (60\% of energy from fat) for 6 weeks. After this period, rats previously fed the HFD were divided into four groups: rats fed the same diet (HFD group), rats fed the HFD supplemented with an extract of Spirulina maxima at a dose of $62.5 \mathrm{mg} / \mathrm{kg}$ body weight/day (Spirulina maxima 62.5), rats fed the HFD supplemented with an extract of Spirulina maxima at a dose of $125 \mathrm{mg} / \mathrm{kg}$ body weight/day (Spirulina maxima 125) 
and rats fed the HFD supplemented with an extract of Spirulina maxima at a dose of $250 \mathrm{mg} / \mathrm{kg}$ body weight/day (Spirulina maxima 250). The cultivated microalgae were harvested by centrifugation (with a tubular separator), stored at $-50{ }^{\circ} \mathrm{C}$ and lyophilized. All Spirulina maxima samples were administered orally for 4 weeks after being dissolved in carboxymethyl cellulose.

The body weight increase induced by high-fat feeding, as well as the increase in white adipose tissue, were significantly reduced after supplementation with Spirulina maxima in a dose-dependent manner. Haemotoxylin and eosin staining of epididymal adipose tissue revealed that the treatment reduced the increase in adipocyte size induced by the HFD at all the tested doses. With regard to brown adipose tissue index, no change was found in the HFD group when compared to the LFD group, but all the treatments with Spirulina maxima induced a significant increase in this parameter. The biochemical analysis revealed that the supplementation with Spirulina maxima attenuated a diet-induced decrease in adiponectin and increase of leptin and tumor necrosis factor $\alpha$ (TNF- $\alpha$ ). It is well-known that obesity is commonly accompanied by insulin resistance, and for this reason serum glucose and insulin levels were also measured, and the Homeostatic Model Assessment for Insulin Resistance (HOMA-IR) was calculated. The Spirulina maxima 250 group showed reduced glucose and insulin levels (insulin levels also in the Spirulina maxima 125 group), and all the tested doses of the microalga diminished HOMA-IR values, reflecting the amelioration in insulin resistance induced by the HFD. In addition, TC was reduced in rats treated with 125 and $250 \mathrm{mg} / \mathrm{kg}$ body weight/day of Spirulina maxima, and the HDL-c/TC ratio was increased at all the tested doses. Furthermore, other parameters were measured in order to estimate the potential toxicity of microalga extract in the liver and kidneys, but all values were found in normal ranges. In the case of alanine aminotransferase (ALT), all doses reduced the increase induced by the HFD.

In order to gain insight into the molecular mechanisms underlying the observed effects, some gene and protein expressions were measured in epididymal adipose tissue and skeletal muscle. In adipose tissue, the HFD reduced the activated form of $5^{\prime}$ AMP-activated protein kinase (pAMPK), which leads to a decreased expression of the phosphorylated form of ACC, which is the inactive form of this enzyme, and increased protein expression of SREBP1 and FAS. The addition of the two highest doses of Spirulina maxima to the diet prevented both these effects as well as the increase in gene expression of Srebp 1 and Fasn. As far as the lipolytic and oxidative pathways are concerned, HFD decreased gene expression of adipose triglyceride lipase $(A t g l)$ and $C p t 1$, whereas that of nuclear factor $\kappa B(N f \kappa B)$ was increased. Those changes were prevented by Spirulina maxima supplementation (Atgl and Cpt1 with the highest dose and $N f \kappa B$ with the two highest doses). As in the case of adipose tissue, the highest two doses of Spirulina maxima activated AMPK in skeletal muscle, and increased Cpt1 and Ucp2 gene expressions. A similar pattern of response was observed in both adipose tissue and skeletal muscle for adiponectin receptor (AdipoR1) in that gene and protein expressions increased in the Spirulina maxima 125 and Spirulina maxima 250 groups. Finally, when the authors analyzed the protein expression of nicotinamide phosphoribosyltransferase (NAMPT) and sirtuin 1 (SIRT1), they observed reduced values in both proteins either in adipose tissue and skeletal muscle from rats fed the HFD, that were prevented by Spirulina maxima treatment.

Another microalga studied for its anti-obesity properties is Phaeodactylum tricornutum. Gille et al. [11] analyzed the effects of this diatom microalga in adipose tissue in mice fed a HFD. For this purpose, male C75BL/6J mice were divided into three experimental groups: the HFD group fed a diet that provided $45 \% \mathrm{kcal}$ from fat (mainly lard), the PE100 group fed the same diet supplemented with an ethanolic extract of the microalga, at a dose of $100 \mathrm{mg} / \mathrm{kg}$ body weight/day, and the PE300 group fed the same diet supplemented with an extract of the microalga, at a dose of $300 \mathrm{mg} / \mathrm{kg}$ body weight/day. Animals were maintained under these experimental conditions for 26 days. At the end of the experimental period, body weight gain, adipose depot weight, adipocyte size distribution, and the expression of lipid and energy metabolism-related genes were analyzed in adipose tissue. Although the energy intake was similar in the three groups, the PE300 group gained less body weight and showed less total body fat mass than the HFD group did. Body weight lost over a 6-h fasting 
period (an indicator of energy expenditure) was higher in the PE300 group. Regarding the fat depots, in PE300 group epididymal and inguinal tissues decreased by $24 \%$ and $17 \%$ respectively, compared to control mice and the PE lowest concentration was without effect. In addition, gene expression of mesoderm-specific transcript homolog protein (Mest), a marker of white adipose tissue expansion, was reduced in inguinal white adipose tissue of mice supplemented with the highest dose of the microalga extract. The authors also found that inguinal white adipose tissue of mice from both PE groups contained higher percentage of smaller adipocytes and lower percentage of large ones. Moreover, in this tissue, crown-like structures (CLS, microscopic foci of dying adipocytes surrounded by macrophages), which were positive for immunostaining against the macrophage marker galectin-3 (MAC-2), were found in all the animals of the PE300 group. Regarding plasma parameters, there was a tendency towards reduced HOMA-IR index only in the group supplemented with PE100, due to the significant decrease in fasting glucose. Moreover, the authors observed that fucoxanthin metabolites, such as fucoxanthinol and amarouciaxanthin were found in interscapular brown adipose tissue, epididymal and inguinal white adipose tissues from mice treated with the microalga extracts.

In order to analyze fatty acid metabolism, the expression of several related genes was measured in epididymal and inguinal white adipose tissues. In epididymal depot hormone sensitive lipase (Hsl), Perilipin 1 (Plin1), and Lpl genes were downregulated, and in inguinal WAT Ucp1 and Cpt1 were upregulated in the PE300 group, indicating higher fatty acid oxidation and thermogenesis in this group. The authors also analyzed brown adipose tissue. The activation of this tissue in PE groups was proposed based on the smaller size of brown adipocytes and the enrichment in UCP1 protein, measured by immunostaining, which was confirmed by Western blot. Finally, brown adipose tissue gene expression of Cd36 and Ppargc1a was also increased in the PE100 group; whereas the lipolytic gene $\mathrm{Hsl}$ (both doses), and the lipogenic gene Fasn (both doses) underwent downregulation.

This microalga was also studied by Koo et al. [10] using a commercially available extract containing $3.5-6 \%$ fucoxanthin $(w / w)$. In this study, which included an in vitro approach previously described in this review, female C57BL/6J mice were divided into six experimental groups. Thus, mice were fed a normal diet (ND), a HFD, or a HFD supplemented with the extract at a dose of $0.81 \mathrm{mg} / \mathrm{kg}$ body weight/day (PE-L), $1.62 \mathrm{mg} / \mathrm{kg}$ body weight/day (PE-M), or $3.25 \mathrm{mg} / \mathrm{kg}$ body weight/day (PE-H). After 6 weeks of treatment, the area under the curve (AUC) of body weights was higher in the HFD group than in the other experimental groups. Phaeodactylum tricornutum extract reduced total fat volume (measured by Micro Computed Tomography Analysis) (at all doses), abdominal adipose tissues (all doses), and subcutaneous depots (PE-M and PE-H groups). When looking at the mechanisms underlying these effects, the authors observed decreased protein expression of the adipogenic factors C/EBP $\alpha$ and PPAR $\gamma$ and increased protein expression of UCP1. Changes in the expressions of PPAR $\gamma$ and UCP1 had been observed in the in vitro experiments performed by these authors (Koo et al. [10]). This fact, linked with the changes to C/EBP $\alpha$ protein expression observed in vivo, suggests that Phaeodactylum tricornutum extract could activate thermogenesis and inhibit adipogenesis. Moreover, regarding plasma lipid profile, some changes were observed in animals treated with the Phaeodactylum tricornutum extract. Thus, while it decreases TG plasma levels at the medium dose (PE-M group), when it was added at a high dose (PE-H group) a decrease in LDL-cholesterol fraction was reported.

In addition to these studies, Kim et al. [16] studied the effect of the same microalgae in C57BL/6 mice. They observed that neither body weight increase, nor food intake were changed along the treatment period, although perirrenal and epididymal adipose depot weights were significantly decreased by the Phaeodactylum tricornutum extract. Due to the fact that these are the only data concerning anti-obesity effects, a longer description was not carried out and it has not been included in the pertinent table.

Sakanoi et al. [14] studied the beneficial effects of a spray-dried Euglena gracilis extract on mice. For this purpose, male C57BL/6J mice were fed a high-sucrose diet supplemented or not with Euglena gracilis extract $(1 \%)$, for 8 weeks. At the end of the experimental period, no changes were observed in body weight or food intake. By contrast, total adipose tissue, perinephric and epididymal fat 
depots were reduced by the extract. mRNA levels of genes related to fatty acid synthesis (Fasn, glucose-6-phosphate dehydrogenase (G6pdh), malic enzyme (Me) and Srebf1), adipogenesis (Ppar $\gamma$ ), and lypolisis $(\mathrm{Hsl})$ were studied. The only change promoted by the microalga extract was an increase in Hsl gene expression. Dyslipidemia is another well-known complication of obesity but under these experimental conditions, serum lipids (TG, cholesterol and phospholipids) were not regulated by Euglena gracilis.

In a recent study conducted by Guo et al. [15], the effect of an extract of Nitzschia laevis, a diatom microalga, was studied. For this purpose, C57BL/6J mice were divided into four experimental groups: the ND group was fed a normal chow diet (4.1\% of energy from fat), the HFD group was fed a high-fat diet (24\% of energy from fat), the HFD-LE group was fed the high-fat diet supplemented with a low-dose of Nitzschia laevis (10 mg/kg body weight/day), and the HFD-HE group was fed the high-fat diet supplemented with a high-dose of Nitzschia laevis $(50 \mathrm{mg} / \mathrm{kg}$ body weight/day). The Nitzschia laevis was administered daily by oral gavage for 8 weeks.

At the end of the experimental period, greater body weights were found in the three HFD-fed groups when compared to the ND group. Of these, the group supplemented with the highest dose of Nitzschia laevis showed lower body weight than that observed in the HFD group. The food intake records confirmed that the body weight-lowering effect was not due to a reduction in food consumption. When the weights of different white adipose tissue depots were analyzed, significantly lower values were appreciated in the epididymal fat depot of both Nitzschia laevis-supplemented groups, without differences between them. A similar pattern was observed in the diameters of the adipocytes of this adipose depot.

As far as brown adipose tissue is concerned, weight was significantly greater in the groups fed the HFD, when compared to the ND group, with no differences among them. By contrast, significantly decreased adipocyte numbers were appreciated in these same groups when compared to the ND group, suggesting that the seaweed supplementation had an adipocyte hypertrophy attenuating effect on these animals. Among the HFD-fed groups, those receiving the microalga supplementation showed increased adipocyte numbers when compared with the HFD group, which reached the ND group values in the case of the group treated with the lower dose. In order to gain a better understanding of the mechanisms that may be involved in the observed effects, gene expression of $U c p 1$ and Pgc-1 $\alpha$ was measured in this tissue. Ucp1 was upregulated in the two Nitzschia laevis-supplemented groups when compared to both the ND and the HFD groups. In the case of $P g c-1 \alpha$ gene expression, an increase was only appreciated in the HFD-LE group, when compared to the other groups. Based on the results reported by the authors, a potential involvement of ucp-1 mediated thermogenesis in the body weight lowering effect observed in the Nitzschia laevis-supplemented groups cannot be ruled out.

In this study, the authors also analyzed the effects of Nitzschia laevis in gut epithelium integrity and gut microbiota. In this regard, they found that HFD feeding significantly decreased the expression of occludin, a plasma membrane protein considered as an important biomarker of the integrity and barrier function of gut epithelium. This deleterious effect was prevented in the HFD-HE group, where values similar to those found in the ND group were reached. In the case of gut microbiota composition, improved species richness and diversity were found in both Nitzschia laevis-supplemented groups when compared to the ND and HFD groups. At the phylum level, the decreased Firmicutes/Bacteroidetes ratio values appreciated in the HFD group was reversed in the two groups supplemented with the microalga, reaching values similar to those observed in the ND group.

Based on the results obtained, the authors concluded that Nitzschia laevis supplementation could be an effective tool in the prevention of body weight induced by HFD feeding in mice. In this regard, the beneficial effects induced by Nitzschia laevis supplementation in gut epithelium integrity and gut microbiota modulation are highlighted as potential underlying mechanisms. 


\section{Human Studies}

Studies addressed in humans devoted to analyzing the anti-obesity effects of microalgae are scarce to date, in comparison to those carried out using in vitro and in vivo experimental models (Table 3). In humans, Spirulina has been used as a dietary supplement for ameliorating a variety of diseases. In this line, Hernández-Lepe et al. [17] carried out a randomized double-blind crossover controlled clinical trial to evaluate the effect of short-term Spirulina maxima supplementation on plasma lipid levels and BMI. For this purpose, young ( $26 \pm 5$ years) sedentary men with BMI $\geq 25 \mathrm{~kg} / \mathrm{m}^{2}$, some of whom suffering from dyslipidemia, were divided into two intervention groups: the Sm group received a supplement of Spirulina maxima $(4.5 \mathrm{~g} /$ day) and the control group received placebo.

The results showed a significant decrease in TC and TG along with a significant increase in HDL-cholesterol in the Sm group after treatment, when compared with the basal levels. These changes were observed only among dyslipidemic subjects. However, LDL-cholesterol showed no change. In addition, the authors compared the variation of each parameter between both experimental groups and observed that plasma TC level decreased significantly in obese subjects in the Sm treatment, and LDL-cholesterol was lower in overweight, obese, and dyslipidemic subjects enrolled in the Sm treatment, when compared to those in the placebo group. By contrast, TG and HDL-cholesterol levels were not modified. As far as BMI is concerned, a significant reduction was only observed in obese and dyslipidemic subjects after treatment. These results suggest that Spirulina maxima supplementation results in a partial improvement of blood lipid profile and BMI in men with excess body weight and dyslipidemia.

Using the same microalga, Szulinska et al. [18] carried out a randomized, double-blind, placebo-controlled trial addressed on 25-60 year old individuals with obesity (BMI $\geq 30 \mathrm{~kg} / \mathrm{m}^{2}$ ), with well-controlled hypertension and without other comorbidities. Participants were divided into two experimental groups: placebo group (four capsules per day of microcrystalline cellulose over 3 months) and spirulina group (four capsules per day of Hawaiian Spirulina over 3 months). Each spirulina capsule contained $0.5 \mathrm{~g}$ of Spirulina maxima. At the end of the experimental period, spirulina group showed lower BMI, waist circumference, serum TC, LDL-cholesterol, glucose and insulin and total antioxidant state than the placebo group. No differences in serum HDL-cholesterol and TG were observed between groups.

In another randomized doubled-blind, placebo-controlled trial conducted by Zeinalian et al. [19], the effect of Spirulina platensis supplementation on BMI, serum lipids, appetite, and serum vascular endothelial growth factor (VEGF) was studied. Individuals with obesity were divided into two groups, the placebo group and the group that received Spirulina platensis twice daily (500 mg each dose). After 12 weeks of intervention, a decrease in body weight, and thus in BMI, was observed, along with a reduction appetite in the group treated with Spirulina platensis. With regard to serum lipids, the only change was a significant reduction in TC, while LDL-cholesterol and TG remained unchanged after the intervention. Despite a significant increase in HDL-cholesterol in both treated and placebo groups at the end of the experimental period, there was no change in the mean differences between the two groups. VEGF is an important angiogenic factor implicated in normal and pathological vessel formation that can be an important biomarker of obesity and obesity-related cancer progression. In this study, VEGF remained unchanged after treatment with Spirulina platensis. The authors concluded that a dose of 1 $\mathrm{g} /$ day of Spirulina platensis for 12 weeks had beneficial effects modulating body weight and appetite, while it only modified the serum lipid profile partially. 
Table 3. Effects of microalgae in clinical studies.

\begin{tabular}{|c|c|c|c|c|}
\hline Reference Numbers & Participants & Microalgae and Doses & Experimental Design & Effects \\
\hline [17] & $\begin{array}{l}52 \text { sedentary young men } \\
\text { ( } 26 \pm 5 \text { years) with } B M I \geq 25 \mathrm{~kg} / \mathrm{m}^{2} \\
27 \text { subjects with overweight and } \\
25 \text { subjects with obesity }\end{array}$ & $\begin{array}{l}\text { Arthrospira (Spirulina) maxima } \\
4.5 \mathrm{~g} / \text { day }\end{array}$ & $\begin{array}{l}\text { Two intervention groups: } \\
\text { Sm: S. maxima supplementation } \\
\text { C: Control (Placebo) } \\
\text { Duration: } 6 \text { weeks }+2 \text { weeks of wash-out } \\
+6 \text { weeks } \\
\text { (crossover for the supplementation } \\
\text { interventions) }\end{array}$ & $\begin{array}{l}\text { Intra-group (pretreatment vs. post) } \\
\text { comparisons (Sm): } \\
\downarrow T C \text { and TG: only in subjects with } \\
\text { dyslipidemia. } \\
\text { LDL-c: no changes } \\
\uparrow \text { HDL-c: only in in subjects with } \\
\text { dyslipidemia. } \\
\text { Inter-group comparisons (Sm vs. C): } \\
\downarrow \text { TC: only in in subjects with obesity. } \\
\text { TG: no changes } \\
\downarrow \text { LDL-c: in in subjects with } \\
\text { overweight, obesity or } \\
\text { dyslipidemia. } \\
\text { HDL-c: no changes } \\
\downarrow \text { BMI: in subjects with obesity or } \\
\text { dyslipidemia. }\end{array}$ \\
\hline [18] & $\begin{array}{l}50 \text { patients ( } 25 \text { women and } 25 \text { men, } \\
25-60 \text { years old) } \\
\text { with obesity }\left(B M I \geq 30 \mathrm{~kg} / \mathrm{m}^{2} \text { ) and }\right. \\
\text { well-controlled hypertension }\end{array}$ & $\begin{array}{l}\text { Arthrospira platensis } \\
\text { Four-daily dosage of } 500 \mathrm{mg} \\
\text { each }\end{array}$ & $\begin{array}{l}\text { Two intervention groups: } \\
\text { Placebo } \\
\text { Spirulina } \\
\text { Duration: } 12 \text { weeks }\end{array}$ & $\begin{array}{l}\text { Effects vs. placebo: } \\
\downarrow \text { BMI and waist circumference } \\
\downarrow \text { Serum TC, LDL-c, glucose, and } \\
\text { insulin } \\
\uparrow \text { Total antioxidant state }\end{array}$ \\
\hline [19] & $\begin{array}{l}56 \text { individuals with obesity } \\
\text { ( } 20-50 \text { years old) with } \\
\text { BMI } \geq 30 \mathrm{~kg} / \mathrm{m}^{2}\end{array}$ & $\begin{array}{l}\text { Arthrospira platensis } \\
\text { Twice-daily dosage of } 500 \mathrm{mg} \\
\text { each }\end{array}$ & $\begin{array}{l}\text { Two intervention groups: } \\
\text { Intervention group: supplementation of } \\
\text { S. platensis in a dosage of } 500 \mathrm{mg} \text { twice a } \\
\text { day over } 12 \text { weeks } \\
\text { Control group: two pills of placebo daily } \\
\text { over } 12 \text { weeks. }\end{array}$ & $\begin{array}{l}\downarrow \text { BMI }(\downarrow \mathrm{BW}) \\
\downarrow \text { TC } \\
\text { TG: no changes } \\
\text { LDL-c: no changes } \\
\text { HDL-c: no changes } \\
\text { VEGF: no changes } \\
\downarrow \text { Appetite }\end{array}$ \\
\hline [20] & $\begin{array}{l}52 \text { subjects with overweight or } \\
\text { obesity with BMI between } 25 \text { and } \\
40 \mathrm{~kg} / \mathrm{m}^{2}\end{array}$ & $\begin{array}{l}\text { Spirulina platensis } \\
\text { Four-daily dosage of } \\
500 \mathrm{mg} / \text { day }\end{array}$ & $\begin{array}{l}\text { Two intervention groups } \\
\text { Intervention SP group: supplementation } \\
\text { of SP extract (four tablets per day) for } \\
12 \text { weeks with a restricted calorie diet } \\
\text { Placebo group: } \\
\text { placebo extract (four tablets per day) for } \\
12 \text { weeks with a restricted calorie diet }\end{array}$ & $\begin{array}{l}\downarrow \text { Body weight } \\
\downarrow \text { Waist circumference } \\
\uparrow \text { Body fat reduction } \\
\downarrow \text { Plasma TG, LDL-c } \\
\downarrow \text { LDL-c/HDL-c ratio }\end{array}$ \\
\hline
\end{tabular}

Special note: Doted lines incorporated for separation between different studies. BMI: body mass index; BW: body weight; C: control (Placebo); HDL-c: high density lipoprotein -cholesterol LDL-c: low density lipoprotein-cholesterol; Sm: Spirulina without exercise; TC: total cholesterol; TG: triglycerides; VEGF: vascular endothelial growth factor. $\uparrow$ significant increase, $\downarrow$ : significant decrease. 
Spirulina platensis was also used in a randomized, double-blinded, placebo-controlled clinical trial reported by Yousefi et al. [20]. Obese or overweight subjects (BMI: $25-40 \mathrm{~kg} / \mathrm{m}^{2}$ ) were distributed into two groups, a placebo and a Spirulina platensis-treated group, who followed a restricted calorie diet for 12 weeks. The microalga was administered in four tablets of $500 \mathrm{mg} / \mathrm{capsule}$ daily. At the end of the intervention, body weight and waist circumference were reduced in the microalga-supplemented group compared to the control group. Moreover, in this group body fat reduction was higher than that observed in the placebo group. Regarding plasma parameters, TG, LDL-cholesterol, and the LDL/HDL ratio were reduced at the end of the treatment period compared with the baseline in the microalga-treated group. Based on these results, the authors suggested that Spirulina platensis could be a useful as a complementary therapy to reduce weight and TG levels.

\section{Concluding Remarks}

Data reported in the literature, and gathered in the present review, show that there is scientific evidence supporting the anti-obesity effect of several microalgae: Euglena gracilis, Phaeodactylum tricornutum, Spirulina maxima, Spirulina platensis, and Nitzschia laevis. With the exception of one study, the published works carried out in animal models have addressed the effects of microalgae in animals submitted to an obesogenic feeding pattern. Consequently, the results have shown the ability of microalgae to total or partially prevent obesity development associated to this dietary pattern.

Preclinical studies have revealed some of the mechanisms of action underlying this effect. Depending on the species and concentration, microalgae can inhibit pre-adipocyte differentiation, thus reducing the number of mature adipocytes ready to accumulate TG. Moreover, they reduce de novo lipogenesis and TG assembly, thus limiting the amount of TG to be stored. An increase in lipolysis and fatty acid oxidation can also be observed. Finally, microalgae can induce an increase in energy expenditure via thermogenesis activation in brown adipose tissue, as well as by inducing browning in white adipose tissue. It could be thought that a potential toxic effect of some constituent common in microalgae could be responsible, at least in part, for the reduced lipid retention and weight reduction. However, this possibility can be discarded because in vitro studies have shown no cytotoxicity of microalgae extracts in a wide range of doses. In parallel with the reduction in body fat accumulation, other features which are typical of individuals with obesity, such as enhanced plasma lipid levels, insulin resistance or diabetes, and low-grade inflammation, are also improved by microalgae treatment.

The anti-obesity effect of microalgae, as well as the improvement of several comorbidities observed in preclinical studies, has been confirmed in clinical trials. In this case, due to the experimental design characteristics, the role of microalgae in obesity treatment, rather than in obesity prevention, has been evidenced.

Concerning the limitations of the reported studies, it should be pointed out that more research is needed to determine which bioactive compounds, present in microalgae, are responsible for their anti-obesity effects, as well as to look for potential synergies among them. In addition, although several mechanisms have been proposed to explain the anti-obesity effects of microalgae, further studies are needed in order to gain more insight concerning this issue. For instance, in several studies increased expression of genes related to thermogenesis has been found, suggesting the activation of this process, but additional studies are needed to confirm that in fact thermogenesis, and consequently energy expenditure, are increased.

Author Contributions: Conceptualization, S.G.-Z. and J.T.; Writing-Original Draft Preparation, S.G.-Z., J.T., M.G.-A., L.A., I.M.-L., M.G., I.E. and A.F.-Q.; Writing-Review and Editing, M.P.P., S.G.-Z., I.E. and A.F.-Q.; Project Administration, M.P.P.; Funding Acquisition, M.P.P. and A.F.-Q. All authors have read and agreed to the published version of the manuscript.

Funding: This study was supported by grants from the Government of the Basque Country (ELKARTEK) under grant KK-2019/00031, Instituto de Salud Carlos III (CIBERobn) under Grant CB12/03/30007, and University of the Basque Country under Grant GIU18-173.

Conflicts of Interest: The authors declare no conflict of interest. 


\section{Abbreviations}

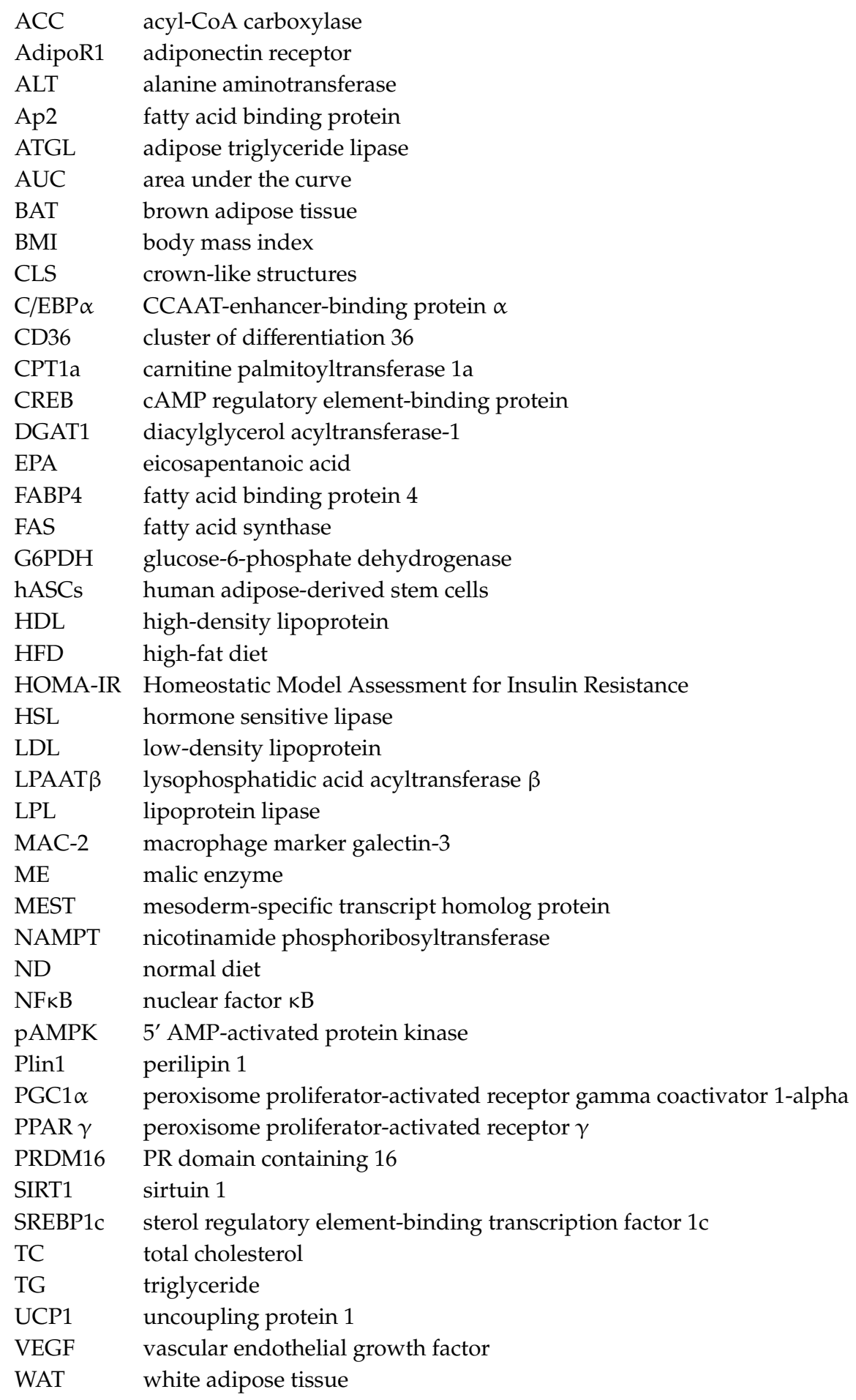




\section{References}

1. Mimouni, V.; Ulmann, L.; Pasquet, V.; Mathieu, M.; Picot, L.; Bougaran, G.; Cadoret, J.P.; Morant-Manceau, A.; Schoefs, B. The potential of microalgae for the production of bioactive molecules of pharmaceutical interest. Curr. Pharm. Biotechnol. 2012, 13, 2733-2750. [CrossRef]

2. Brennan, L.; Owende, P. Biofuels from microalgae-A review of technologies for production, processing, and extractions of biofuels and co-products. Renew. Sust. Energ. Rev. 2010, 14, 557-577. [CrossRef]

3. Khan, M.I.; Shin, J.H.; Kim, J.D. The promising future of microalgae: Current status, challenges, and optimization of a sustainable and renewable industry for biofuels, feed, and other products. Microb. Cell Fact. 2018, 17, 36. [CrossRef] [PubMed]

4. Guh, D.P.; Zhang, W.; Bansback, N.; Amarsi, Z.; Birmingham, C.L.; Anis, A.H. The incidence of co-morbidities related to obesity and overweight: A systematic review and meta-analysis. BMC Public Health 2009, 9, 88. [CrossRef] [PubMed]

5. Allott, E.H.; Hursting, S.D. Obesity and cancer: Mechanistic insights from transdisciplinary studies. Endocr Relat. Cancer 2015, 22, R365-R386. [CrossRef] [PubMed]

6. Abdelaal, M.; le Roux, C.W.; Docherty, N.G. Morbidity and mortality associated with obesity. Ann. Transl Med. 2017, 5, 161. [CrossRef] [PubMed]

7. Patel, D.K.; Stanford, F.C. Safety and tolerability of new-generation anti-obesity medications: A narrative review. Postgrad. Med. 2018, 130, 173-182. [CrossRef] [PubMed]

8. Sugimoto, R.; Ishibashi-Ohgo, N.; Atsuji, K.; Miwa, Y.; Iwata, O.; Nakashima, A.; Suzuki, K. Euglena extract suppresses adipocyte-differentiation in human adipose-derived stem cells. PLoS ONE 2018, 13, e0192404. [CrossRef] [PubMed]

9. Seo, Y.J.; Kim, K.J.; Choi, J.; Koh, E.J.; Lee, B.Y. Spirulina maxima extract reduces obesity through suppression of adipogenesis and activation of browning in 3T3-L1 cells and high-fat diet-induced obese mice. Nutrients 2018, 10, 712. [CrossRef] [PubMed]

10. Koo, S.Y.; Hwang, J.H.; Yang, S.H.; Um, J.I.; Hong, K.W.; Kang, K.; Pan, C.H.; Hwang, K.T.; Kim, S.M. Anti-Obesity Effect of Standardized Extract of Microalga Phaeodactylum tricornutum Containing Fucoxanthin. Mar. Drugs 2019, 17, 311. [CrossRef] [PubMed]

11. Gille, A.; Stojnic, B.; Derwenskus, F.; Trautmann, A.; Schmid-Staiger, U.; Posten, C.; Briviba, K.; Palou, A.; Bonet, M.L.; Ribot, J. A Lipophilic Fucoxanthin-Rich Phaeodactylum tricornutum Extract Ameliorates Effects of Diet-Induced Obesity in C57BL/6J Mice. Nutrients 2019, 11, 796. [CrossRef] [PubMed]

12. Lefterova, M.I.; Lazar, M.A. New developments in adipogenesis. Trends Endocrinol. Metab. 2009, 20, 107-114. [CrossRef] [PubMed]

13. Heo, M.G.; Choung, S.Y. Anti-obesity effects of Spirulina maxima in high fat diet induced obese rats via the activation of AMPK pathway and SIRT1. Food Funct. 2018, 9, 4906-4915. [CrossRef] [PubMed]

14. Sakanoi, Y.; Shuang, E.; Yamamoto, K.; Ota, T.; Seki, K.; Imai, M.; Ota, R.; Asayama, Y.; Nakashima, A.; Suzuki, K.; et al. Simultaneous Intake of Euglena Gracilis and Vegetables Synergistically Exerts an Anti-Inflammatory Effect and Attenuates Visceral Fat Accumulation by Affecting Gut Microbiota in Mice. Nutrients 2018, 10, 1417. [CrossRef] [PubMed]

15. Guo, B.; Liu, B.; Wei, H.; Cheng, K.W.; Chen, F. Extract of the Microalga Nitzschia laevis Prevents High-Fat-Diet-Induced Obesity in Mice by Modulating the Composition of Gut Microbiota. Mol. Nutr. Food Res. 2019, 63, e1800808. [CrossRef] [PubMed]

16. Kim, J.H.; Kim, S.M.; Cha, K.H.; Mok, I.K.; Koo, S.Y.; Pan, C.H.; Lee, J.K. Evaluation of the anti-obesity effect of the microalga Phaeodactylum tricornutum. Appl. Biol. Chem. 2016, 59, 283-290. [CrossRef]

17. Hernández-Lepe, M.A.; Wall-Medrano, A.; López-Díaz, J.A.; Juárez-Oropeza, M.A.; Hernández-Torres, R.P.; Ramos-Jiménez, A. Hypolipidemic Effect of Arthrospira (Spirulina) maxima Supplementation and a Systematic Physical Exercise Program in Overweight and Obese Men: A Double-Blind, Randomized, and Crossover Controlled Trial. Mar. Drugs 2019, 17, 270. [CrossRef] [PubMed]

18. Szulinska, M.; Gibas-Dorna, M.; Miller-Kasprzak, E.; Suliburska, J.; Miczke, A.; Walczak-Gałezewska, M.; Stelmach-Mardas, M.; Walkowiak, J.; Bogdanski, P. Spirulina maxima improves insulin sensitivity, lipid profile, and total antioxidant status in obese patients with well-treated hypertension: A randomized double-blind placebo-controlled study. Eur Rev. Med. Pharmacol. Sci. 2017, 21, 2473-2481. [PubMed] 
19. Zeinalian, R.; Farhangi, M.A.; Shariat, A.; Saghafi-Asl, M. The effects of Spirulina Platensis on anthropometric indices, appetite, lipid profile and serum vascular endothelial growth factor (VEGF) in obese individuals: A randomized double blinded placebo controlled trial. BMC Complement. Altern. Med. 2017, 17, 225. [CrossRef] [PubMed]

20. Yousefi, R.; Mottaghi, A.; Saidpour, A. Spirulina platensis effectively ameliorates anthropometric measurements and obesity-related metabolic disorders in obese or overweight healthy individuals: A randomized controlled trial. Complement. Ther. Med. 2018, 40, 106-112. [CrossRef] [PubMed]

(C) 2019 by the authors. Licensee MDPI, Basel, Switzerland. This article is an open access article distributed under the terms and conditions of the Creative Commons Attribution (CC BY) license (http://creativecommons.org/licenses/by/4.0/). 